\title{
CUTIS VERTICIS GYRATA - A RARE CASE REPORT
}

Gopal M.G'1, Meena H.B², Sharath Kumar B.C ${ }^{3}$, Ramesh Mㄴ, Nandini A.S 5

\section{HOW TO CITE THIS ARTICLE:}

Gopal MG, Meena HB, Sharath Kumar BC, Ramesh M, Nandini AS. "Cutis verticis gyrata - a rare case report". Journal of Evolution of Medical and Dental Sciences 2013; Vol. 2, Issue 49, December 09; Page: 9481-9484.

ABSTRACT: Cutis verticis gyrata (CVG) is a skin deformity characterised by excessive growth of skin of the scalp, resulting in furrows and folds which are similar to gyri of the brain cortex. A 25 year old male presented to the Dermatology department, Kempegowda institute of medical sciences with increased skin folds over scalp, forehead and face, increased oiliness of face, increased sweating, swelling of hands and feet and pain in limbs since 4 years. Routine blood investigation, thyroid function test and chest x-ray were normal Skull x-ray, x-ray of hands and feet showed cortical thickening of bones. CONCLUSION: We are presenting this case of CVG secondary to pachydermoperiostosis which is a rare case.

KEY WORDS: Cutis verticis gyrate, pachydermoperiostosis

INTRODUCTION: Alibert first mentioned cutis verticis gyrata, Robert described the condition in 1843. Unna introduced the term cutis verticis gyrata in $1907(!)$

The directions of the folds are usually anterior to posterior, but may be transverse over the occipital region.Less often, they may be irregularly situated. Different collections of cell types may be responsible for outward convoluted appearance ranging from inflammatory or hamartomatous infiltrations to neoplastic proliferations

CASE REPORT: A 23 year old male presented to us with history of increased folds over the scalp and forehead, increased oiliness of face excessive sweating, swelling of hands and feet ,Pain in the limbs since 4 years. He had no history of any inflammatory condition of his skin or scalp. No history of seizure, mental retardation, cerebral palsy, eye disorder, thyroid problem, tumour or trauma. No family history of consanguinity. On examination there was thickening of skin, deep folds and furrows of skin over forehead, (fig. 1) and scalp (fig. 2) with convoluted ,cerebriform and gyrate appearance, worried expression of the face. Sebaceous hyperplasia (fig. 3) and extrusion of sebaceous secretion over the nose (fig. 4) with spade like digits and clubbing (fig. 5)excessive sweating was also noticed Investigations revealed normal routine haematological and thyroid function test. Chest X-ray was normal. (fig. 6) Skull X-ray (fig. 7) X-ray of hands (fig. 8) and foot (fig. 9) showed thickening of bones

With the history, examination and investigation report a final diagnosis of cutis verticis gyrate secondary to pachydermoperostosis type 3 forme froste was made.

DISCUSSION: Polan and Butterworth(2) established the classification of cutis verticis gyrata in 1953, dividing cutis verticis gyrata into primary and secondary forms.

In 1984, Garden and Robinson(3) improved the classification by proposing new terms: primary essential cutis verticis gyrata for cases in which no other abnormality was found (rare) and primary nonessential, which can be associated with mental deficiency, cerebral palsy, epilepsy, schizophrenia, cranial abnormalities (microcephaly), deafness, ophthalmologic abnormalities (cataract, strabismus, blindness, retinitis pigmentosa), or a combination of these. 
Secondary cases of cutis verticis gyrata are associated with the following underlying diseases as mentioned in table below

\begin{tabular}{|ll|}
\hline \hline Type of CVG & Associated disease \\
\hline Primary essential CVG & None \\
Primary nonessential CVG & Neurological: seizures, mental \\
& retardation \\
Secondary & - Acromer: cataracts, optic atrophy \\
& - Amyloidosis \\
& - Cylindroma \\
& - Fonnective tissue nevus \\
& - Klinefelter syndrome \\
& - Leukemia \\
& - Myxedema \\
& - Nelanocytic nevi/hamartomas \\
& - Nevus lipomatosus \\
& - Noonan syndrome \\
& - Tuberous sclerosis \\
& - Turner syndrome \\
\hline CVG: Cutis verticis gyrata & \\
\hline
\end{tabular}

In our case a diagnosis of cutis verticis gyrate secondary to pachydermoperiostosis was made.

Pachydermoperiostosis or primary hypertrophic osteoarthropathy is a rare hereditary. It is characterized by digital clubbing, pachydermia (thickening of the facial skin and/or scalp), and periostosis (swelling of periarticular tissue and subperiosteal new bone formation). Pachydermoperiostosis or primary hypertropic osteoarthropathy is associated with pain, polyarthritis, cutis verticis gyrate (4) seborrhea, eyelid ptosis, ${ }^{(5,6)}$ and hyperhidrosis. Touraine et al(7) described 3 forms of pachydermoperiostosis or primary hypertrophic osteoarthropathy: (1) a complete form with pachydermia and periostitis, (2) an incomplete form with evidence of bone abnormalities but lacking pachydermia, and (3) a forme fruste with prominent pachydermia and minimal-to-absent skeletal changes

Treatment of cutis verticis gyrata includes treating the secondary causes, CVG is a cosmetic problem, but psychological repercussions are important. Education of patients with cutis verticis gyrata with proper hygiene of the scalp is essential to avoid the accumulation of secretion in the furrows and secondary infections, surgical resection of the lesions for psychological or esthetic (8) reasons. Neurologist consultation for underlying neurologic process. Ophthalmologist consultation for underlying ophthalmologic abnormality

CONCLUSION: Cutis verticis gyrate in our case was secondary to Pachydermoperiostosis - type 3 forme fruste type and patient was treated with NSAID, genetic and psychological counseling with reassurance. It is important to differentiate primary CVG and secondary CVG and if secondary due to which condition so that appropriate treatment is given to the patient.

\section{REFERENCES:}

1. Unna PG. Cutis verticis gyrata. Monatschr Prakt Derm. 1907;45:227-33. 
2. Polan S, Butterworth T. Cutis verticis gyrata; a review with report of seven new cases. Am J Ment Defic. Apr 1953;57(4):613-31. [Medline].

3. Garden JM, Robinson JK. Essential primary cutis verticis gyrata. Treatment with the scalp reduction procedure. Arch Dermatol. Nov 1984;120 (11):1480-3. [Medline].

4. Sandoval AR, Robles BJ, Llanos JC, Porres S, Dardón JD, Harrison RM. Cutis verticis gyrata as a clinical manifestation of Touraine-Solente-Gole' syndrome (pachydermoperiostosis). BMJ Case Rep. Jul 12 2013;2013:[Medline].

5. Alves AP, Holanda Filha JG, et al. [Eyelid ptosis associated with pachydermoperiostosis: case report.]. Arq Bras Oftalmol. May-Jun 2005;68 (3):401-4. [Medline].

6. Arinci A, Tümerdem B, Karan MA, et al. Ptosis caused by pachydermoperiostosis. Ann Plast Surg. Sep 2002;49(3):322-5. [Medline].

7. Touraine A, Solente G, Gole L. Un syndrome osteodermopathique: la pachydermie plicaturee avec pachyperiostose ds extremites. Presse Med. 1935;43:1820-4.

8. Radwanski HN, Rocha Almeida MW, Pitanguy I. Primary essential cutis verticis gyrata - a case report. J Plast Reconstr Aesthet Surg. Oct 22 2008;[Medline]. 2010.

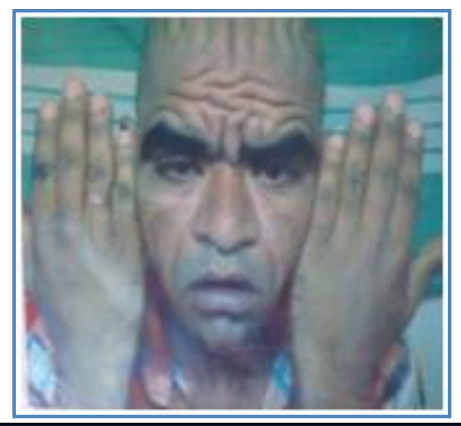

Fig. 1: Cerebriform Gyrate Folds over the forehead

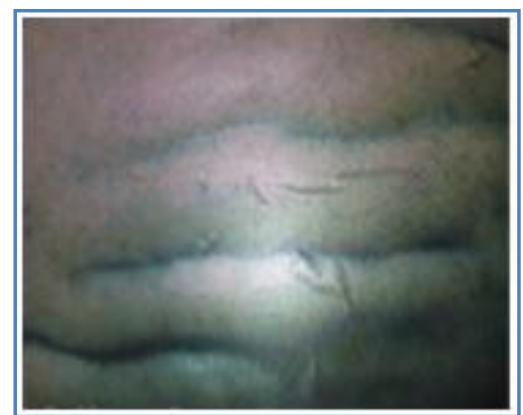

Fig. 2: Cerebriform Gyrate Folds over the Scalp

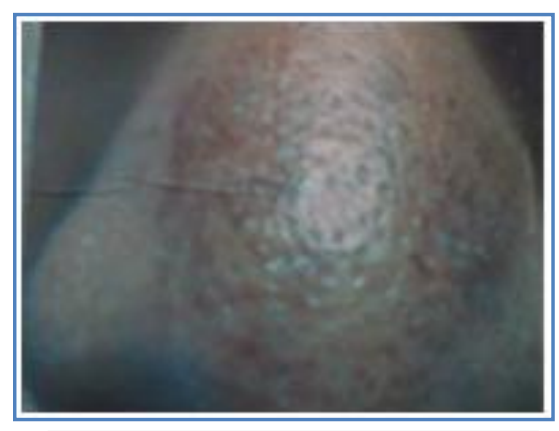

Fig. 3: Sebaceous Hyperplasia over the nose

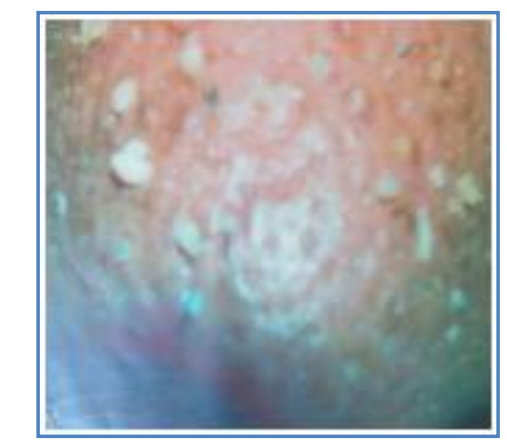

Fig. 4: Extruding Sebaceous secretion

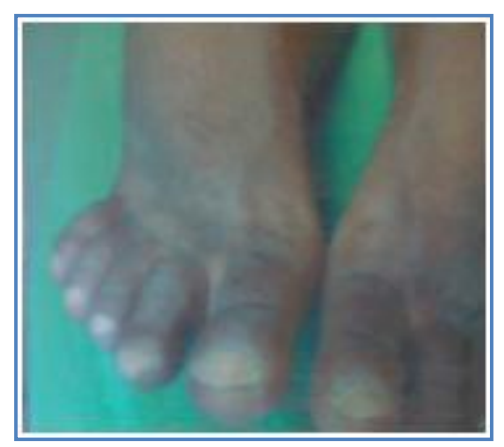

Fig. 5: Showing Spade like digits and clubbing

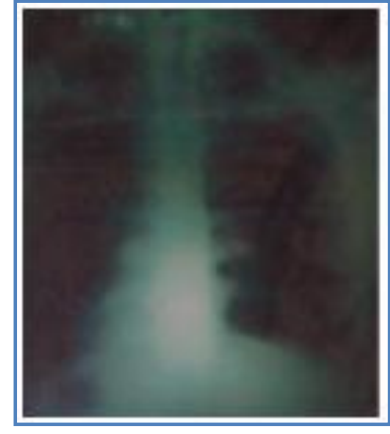

Fig. 6: Normal Chest X-Ray 


\section{CASE REPORT}

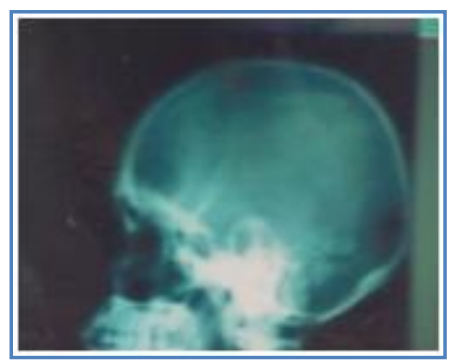

Fig. 7: Normal Skull X- Ray

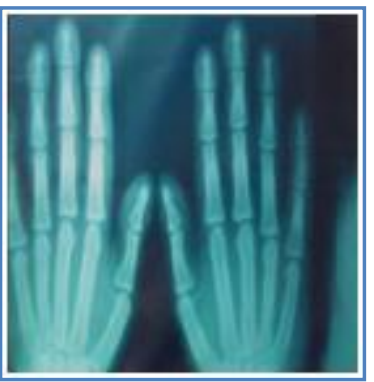

Fig. 8: X- Ray of hand showing Cortical thickening of bones

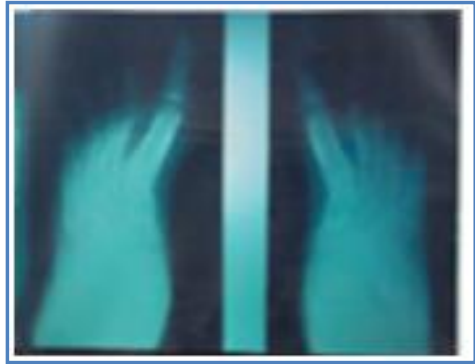

Fig. 9: X-Ray of foot showing thickening of bones

\section{AUTHORS:}

1. Gopal M.G.

2. Meena H.B.

3. Sharath Kumar B.C.

4. Ramesh M.

5. Nandini A.S.

\section{PARTICULARS OF CONTRIBUTORS:}

1. Professor and HOD, Department of Dermatology, Kempegowda Institute of Medical Sciences.

2. $2^{\text {nd }}$ Year Post Graduate, Department of Dermatology, Kempegowda Institute of Medical Sciences.

3. Professor, Department of Dermatology, Kempegowda Institute of Medical Sciences.
4. Associate Professor, Department of Dermatology, Kempegowda Institute of Medical Sciences.

5. Assistant Professor, Department of Dermatology, Kempegowda Institute of Medical Sciences.

\section{NAME ADDRESS EMAIL ID OF THE CORRESPONDING AUTHOR:}

Dr. M.G. Gopal, $3793,13^{\text {th }}$ Cross, $21^{\text {st }}$ Main, Banashankari, $2^{\text {nd }}$ Stage,

Bangalore.

Email -gopalamg@yahoo.co.in

Date of Submission: 14/11/2013.

Date of Peer Review: 15/11/2013.

Date of Acceptance: 22/11/2013.

Date of Publishing: 03/12/2013. 